\title{
Validating the Relationship Management Maturity Concept
}

\subsection{The Design of a Research Tool ON RM MATURITY}

The aim of empirical studies in management sciences is to reproduce and elucidate any given business phenomenon without contaminating the research with subjective prejudices concealed in its design or with an authoritative interpretation of the data (Czakon 2015). However, this is not entirely possible as, to a large extent, management sciences involve studying value-laden phenomena, which are not neutral either to the researcher or to the people who are interviewed, observed or tested (Alvesson and Deetz 2000).

In quantitative studies the risk of contaminating the research by the author's preferences is located in the design of the research tool (questionnaire), the choice of analytical tool (statistical methods) and the (mis-)interpretation of extracted data (Ketokivi and Mantere 2010). Moreover, in self-reporting studies, such as the one applied in this book, the results may be biased by the co-occurrence of several behavioural and psychological effects affecting the likelihood that the respondents will be willing or able to inform about the true state of affairs (Donaldson and Grant-Vallone 2002).

Critical positive or negative events may trigger various self-efficacy and defence mechanisms, which change the response lens of the interviewee

(C) The Author(s) 2021

B. Deszczyński, Firm Competitive Advantage Through Relationship

Management, https://doi.org/10.1007/978-3-030-67338-3_4 
(Davidson and MacGregor 1998; Kihlstrom et al. 1999). Acquiescence response style (answering predominately positively especially on questions concerning issues the respondent is not knowledgeable of) or extreme/ mid-point response styles (concentrating predominately on a specific scale area regardless of the questioned matter) may bias the results particularly where cross-cultural research is concerned (Clarke 2001; de Jong et al. 2008).

Studies in organizational behaviour in particular are prone to selfreporting bias because the interviewees often believe there is at least a remote possibility that their employer could gain access to their responses (Donaldson and Grant-Vallone 2002). Therefore, leniency or harshness may bias the responses, especially when the questions concern behaviour of the leader/supervisor (Marsh and Roche 2000; Schriesheim 1981). By contrast, so-called managerial sense-making is a product of the combined effects of critical events and individual reality perception, such as selfesteem or cognitive consistency (March and Sutton 1997). These cause managers to report positive aspects of their own capability beyond what is true and stretch to the overall corporate reality perception, especially if the company is performing well (Chandra and Wilkinson 2017; Rong and Wilkinson 2011).

The overall tendency for people to present, regardless of social context, a favourable image of themselves is known as socially desirable responding (Helgeson and Supphellen 2004). Although there are tools effective in uncovering, for example, the tendency towards self-promotion on questionnaires, such as the Crowne-Marlowe Social Desirability Scale (1960), their use is limited, not least because of the feasibility of such tests (this social desirability scale consists of 33 items; van de Mortel 2008). Nonetheless, questionnaires are easy and effective tools to administer in large-scale testing, and are suitable for delivering high-quality results provided a deliberate bias reduction strategy is applied (Krosnick 1999). Such a strategy must minimize the sampling and non-sampling errors by applying various statistical and non-statistical measures. The statistical biasreducing measures undertaken in this research will be described in Sect. 4.2, 'Analytical strategy'. Still, many of the non-sampling errors, such as specification and measurement errors, come as the effects of these researcher and respondent preferences (Biemer 2010). These problems should be addressed in the questionnaire design by applying appropriate linguistic forms and by using and interpreting measuring scales. 
While conducting the literature review for this book, the applied questionnaires were found to quite frequently use terms which are either very general and prone to interpretation or hard to comprehend at all. The examples include such expressions as "We share the same feelings towards things around us", "Communications are accurate", "The supply chain is managed holistically", "We work in close cooperation", "We are good at creating/maintaining relationships with key customers" and "We both try very hard to establish a long-term relationship". The countless possible interpretations of the degree of 'communication accuracy', or of 'being good at something', and the overlaps in perceived meaning of abstract expressions may easily turn the answers to such questions into an incompatible dataset (Palmatier 2008). Therefore, the questionnaire applied in this research, for example, specifies the frequency of particular activities instead of leaving blank expressions such as 'systematically' or 'timely', and requires taking clear positions towards managing concrete processes instead of offering comfortable responses such as 'We attempt to manage process X'.

The other risk is that the accumulation of ambiguous RM characteristics could negatively affect the respondents' concentration and motivation to make meaningful discriminations (Alwin 2007). Such a questionnaire design would instead press them to accommodate in language conventions of positive statements or tautologies rather than to kick back with alternative paths of reasoning, especially if the interview focuses on business performance or effectiveness (Alvesson and Deetz 2000). Uncovering a genuine assessment of the state of affairs also implies avoiding the use of complex systems of judgemental statements, for example:

- A. You are an RM-mature company because you co-create value with customers;

- A.l. Your value co-creation offers make customers satisfied;

- A.2. Loyalty comes as the result of satisfying customers with your value co-creation efforts.

Placed in a fixed leader-follower structure with clearly visible interdependencies, they would cause the respondents to take the implicit researcher view rather to reflect their own. Therefore, staying in line with principle 2 of research design defined in Chap. 3, special effort was taken to ensure that the expressions used in the questionnaire on RM maturity are describing, in a possibly concrete and neutral way, social or business reality rather 
than individual or shared subjective feelings, impressions, stereotypes, cognitions or perceptions (Alvesson and Sköldberg 2009).

As a result, most of the questions contain complex descriptions, which, at first glance, may leave the impression of asking about many issues without providing the possibility to differentiate the answers. Obviously, applying double-barrelled questions would be a fallacy (Adèr 2008; Rowley 2014). Yet, the proposed descriptions highlight nuances of the same phenomenon and, in fact, only combined describe the postulated state of maturity in a given action or approach. For example, take question D03 listed in Table 4.1, which refers to the maturity in managing customer leads. It would not be enough for a company just to (1) immediately service every customer who is looking for the offer without making sure that (2) these contacts are also registered and processed to salespersons and that $(3)$ the conversion rates are measured. Hence, breaking this process into three separate questions $(1,2,3)$ would unnecessarily extend the length of the interviewing procedure and would make it impossible to fully assess the lead management maturity. If a company were to report score ' 10 ' for ( 1 ) and (3) and score ' 5 ' for (2) the mean would fall as much as 8.33 . Nonetheless, the logic suggests that if leads are systematically dropped while being processed to the salesperson, ( 1 ) is like making an attempt to fill a leaky bucket and (3) is like measuring the fever without actually reading the result.

One could also argue that the applied questions break the other rule of thumb for designing questionnaires, that is, to keep the questions short and simple (Dörnyei and Taguchi 2009; Foddy 1994). However, a question/statement such as "We are good in managing leads", which indeed sounds simple, would likely leave most of the respondents feeling comfortable in giving a 'strongly agree' or reporting a high score in the hypothetical situation presented above. There is no doubt that questions containing complex descriptions require more time to comprehend than short ones. In this study, however, saving time was not a priority, because collecting inconsiderate superficial answers would seriously compromise the application of theory-methodic hypothesis Hltm. Instead, before venturing to collect the bulk of the data, the questionnaire was first tested and corrected in direct interviews and in pilot field research to ensure that all questions could be well explained to and understood by the interviewees (for details see Sect. 4.2, 'Analytical strategy').

The questionnaire displayed in Table 4.1 comprises 40 questions grouped in 3 dimensions, strategy, ICT, and interdepartmental and 
Table 4.1 The questionnaire on RM maturity

\section{Code Dimension 1: Strategy}

A01 The company has a business plan (business strategy) with a central element which is to nurture long-term relationships with its employees and customers.

A02 Ethical behaviour forms part of the corporate strategy, including fairness towards business partners as well as an active commitment to the well-being of the local community, the natural environment and contribution to people in need.

A03 The company knows the answers to the following questions:

Who?: Who are our customers?

What?: What kind of needs do they have?

When?: When is the next purchase likely to occur?

A04 The company manages relationships with business partners other than customers (suppliers, distributors, etc.) and can, in turn, assess, for example:

- the quantitative scale of cooperation: The interdependence between quantitative plans, for example manufacturing or sales plans and particular partners;

- the quality of cooperation: The influence of a particular partner on the exact timing of planned operations, manufacturing quality control, customer service and so forth;

- cooperation perspectives: The importance of a particular partner for product innovation, sales growth and so forth.

A05 The company knows its best customers and tailors its offer to their individual preferences (products, services, forms of cooperation), and if relationship economics allow this, it provides additional benefits (e.g. servicing priority, personal advisors, earlier access to products, exclusive amenities).

A06 Based on registered information (e.g. offers sent, previous purchases, purchases at competitors), the company differentiates its offer for every direct customer.

A07 The company favours and promotes employees who:

- have a command of valuable, rare and hard-to-learn capabilities,

- have a high level of work engagement.

A08 In the company, there is a knowledge management process supervised by a high-ranking manager (a member of the management board or a manager directly reporting to the board).

\section{Code Dimension 2: ICT - CRM systems}

B01 When servicing customers, employees use solely one system (one window), which supports the whole process and integrates all relevant customer data $\left(360^{\circ}\right.$ customer view principle).

B02 The CRM system has significantly accelerated the reporting of customer frontline processes (including marketing processes) - There is no need for manual work on weekly or monthly reports.

B03 The company uses a central database (data warehouse), which:

- integrates information produced by all customer data processing applications,

- enables analytical work (e.g. customer defection prediction). 
Table 4.1 (continued)

B04 The CRM implementation and development project is:

- coordinated by a project manager who understands the potential and the limits of information technologies, but originates from a non-IT department,

- is actively supported by a member of the management board or a manager directly reporting to the board.

B05 The CRM implementation and development project engaged:

- employees with high authority among future system users,

- owners of processes to be digitalized.

B06 The company has prepared a detailed CRM business implementation plan

(detailed $=$ the report includes measurable benefits, e.g. improvement in marketing conversion).

B07 The company enriches individual customer/partner data stored in the CRM system by their respective social profiles.

\section{Code Dimension 2: ICT - Other systems}

B08 The HR department uses a system which enables a search for candidates who have the characteristics and capabilities that match the requirements in current recruitments among:

- present and former employees,

- trainees and former applicants.

B09 Thanks to access to an internal HR IT system, many everyday matters are dealt with by employees themselves (e.g. taking holidays, settling business trip expenses, participation in training programmes).

B10 Employees are using, on a daily basis, a knowledge management system, which helps in the storage and search of:

- know-what knowledge (facts, procedures, processes),

- know-who knowledge (knowledgeable employees).

B11 The company uses an IT system which enables informal communication among employees, based on social media-like tools (e.g. chat, forum, blog).

Code Dimension 3: Processes - Interdepartmental

C01 Professional skills, taking care of customers and employees, as well as the ethical behaviour of the company leadership, is the benchmark for all employees.

C02 Customer satisfaction, loyalty and engagement indicators are analysed by the company's top management at least once a month, and if necessary, immediate problem-solving corrections are implemented.

C03 The company actively promotes and appreciates such values and attitudes as:

- sincere interest in customer needs,

- openness for collaboration within the company and with external partners,

- respect for every person,

- care for corporate property,

- openness to taking on challenges and taking risks, as well as the readiness to learn from mistakes. 
Table 4.1 (continued)

C04 Clear procedures describing the ways important corporate data can be accessed do not cause employees to complain about bureaucratic barriers or a reluctance of fellow-employees, when asked for information sharing or interpretation.

C05 Employees are encouraged to come up with innovative ideas. Every such idea is assessed, and the authors of the best ideas are given a chance to implement them (e.g. they manage the change management project).

C06 The managers at any level devote much more time to motivating and leading their teams than to detailed work division and control.

C07 The employees willingly engage in corporate social responsibility actions of their employer (e.g. working together to help charities, raising money in collections, taking part in educational, health-promoting or environmental protection activities).

C08 A sympathetic and open working ambience creates a corporate environment where professional subordination and belonging to different departments do not harm good communication and cooperation among employees.

C09 Employee mobility is encouraged by offering a chance to participate in interdepartmental projects or teams.

Code Dimension 3: Processes - Departmental

D01 Tailor-made offers for loyal customers are usually more beneficial than offers for new customers.

D02 Sales planning is foremostly based on loyal customer purchases, and efforts are made to systematically take advantage of their referrals.

D03 The company is confident that:

- every customer looking for information about an offer is serviced immediately,

- these contacts are registered and processed to salespersons,

- the sales conversion of these customers is constantly monitored.

D04 Every customer is offered add-ons, such as:

- complementary products (e.g. accessories, financial services),

- up-sell products.

These proposals are based on customer data registered by the company.

D05 Means of direct communication are the main communication tools. The communications select:

- meaningful content (tailored to customer needs),

- communication channels,

- exact time (incorporating the individual product/service use cycle).

D06 The company or its brands have built a continuously engaged online community helpful in:

- proliferation and creative transformation of its marketing communication,

- inspiring new products and services,

- acquiring new customers. 
Table 4.1 (continued)

D07 Customer service does not only address dispute issues, but actively counters defection. Hence this unit has its own budget, which (provided there is a business reason) is used to resolve problems in favour of the customer, even if the factual terms the customer requests are unjustifiable.

D08 Customer feedback (e.g. complaints, requests):

- is discussed by the employees concerned and their supervisors within one week after the event occurs,

- analysis is included in the employee assessment system.

D09 Employee assessment is based on:

- work performance indicators and the supervisor's evaluation,

- opinions of fellow-employees, regarding their engagement, knowledge and willingness to cooperate,

- self-assessment,

- in the case of additional managers on their team's engagement, knowledge and a willingness to cooperate.

D10 The following initiatives are organized:

- numerous internal training sessions (conducted by the company's own employees)

And

- new talent development programmes, supervised by experienced employees where the company's know-how is effectively transferred.

D11 The company, on a regular basis, monitors indicators such as:

- RFM - Recency, frequency, monetary value of customer purchases,

- NPS - Customer propensity to refer the offer,

- CLV - Customer lifetime value (the extrapolated value of customer purchases in the envisaged loyalty cycles).

D12 The company, on a regular basis, monitors customer and employee engagement based on indicators such as:

- openness to communication (e.g. participation in surveys),

- propensity to refer the company (as a supplier or an employer),

- reporting new ideas (e.g. products, services, improvements).

Code Company characteristics

E01 The company has (a single-choice question):

E1.1 fewer than 100 customers,

E1.2 several hundred customers,

E1.3 1000 or more customers.

E02 The company has (a single-choice question):

E2.1 $<10$ employees,

E2 $2<50$ employees,

E2.3 $<250$ employees,

E2.4< 999 employees,

E2.5 4999 employees,

E2.6 $=>5000$ employees.

(continued) 
Table 4.1 (continued)

E03 Market focus (a single-choice question):

E3.1 business-to-customer,

E3.2 business-to-business,

E3.3 business-to-administration.

E04 The company's business model is mainly based on (a single-choice question):

E4.1 agriculture,

E4.2 production without commerce structures,

E4.3 production with commerce structures,

E4.4 production with commerce structures and customer service,

E4.5 production with commerce structures, customer service and augmented

services,

E4.6 commerce,

E4.7 commerce and customer service,

E4.8 commerce, customer service and augmented services,

E4.9 services,

E4.10 services with commerce structures,

E4.11 research and development.

E05 The company's main industry, according to polish classification of business activities (a single-choice question):

E5.1 agriculture,

E5.2 wholesale trade,

E5.3 retail,

E5.4 construction,

E5.5 transport,

E5.6 financial services,

E5.7 communication and information technologies,

E5.8 other services,

E5.9 production,

E5.10 mining.

E06 Which description best suits the way your company is managed (a singlechoice question):

E6.1 strong leadership and centralization in the hands of the owner/president of the company,

E6.2 centralization of decisions in the hands of top management, multiple layers of management, work standardization and formalization, big organizational units, E6.3 decisions in the hands of multiple types of managers and highly qualified specialists, big organizational units,

E6.4 high degree of independence of business units (geographically or product related) supervised based on an extensive system of KPIs,

E6.5 decisions democratically resulting from the opinions of many employees, small organizational units and matrix structures. 
Table 4.1 (continued)

E07 During the last two years the company has (multiple choice):

E7.1 been steadily expanding in terms of sales or market share,

E7.2 been steadily staying ahead of competitors in terms of profits,

E7.3 entered a new market,

E7.4 been steadily increasing employment,

E7.5 taken over (an)other enterprise(s),

E7.6 been steadily staying ahead of competitors in terms of customer satisfaction,

E7.7 been steadily improving the customer loyalty rate,

E7.8 been steadily a sought-after employer.

The items from group A, C, D, which are given in bold were incorporated in the final proposal of the RM maturity model.

departmental processes, which mirror the $13 \mathrm{RM}$ themes discussed in the previous chapter. The RM-based service logic is implied in all but the ICT dimensions. Eight questions in the 'strategy' dimension deal with the general approach to baseline RM facets reflected in corporate documents and core capabilities. Eleven questions in the ICT section focus on the functionality and implementation process of CRM-class systems as well as other ICT instances. Two groups of, in total, 21 questions in the processual dimension reflect concrete RM activities that may characterize an RM-mature firm. In addition, in line with principle 3 of research design defined in Chap. 3, seven multiple-choice questions concerning different company characteristics, including its competitive advantage, were placed in section E.

As indicated in Chap. 1, the notion of competitive advantage is a relative phenomenon. Competitive advantage is also not only about generating temporary profits, but about the potential to sustain this ability in the future. Therefore, in this questionnaire the usual short-term financial and market measures of competitive advantage were supplemented with some future-oriented ones, focused on customer and employee value (Feurer and Chaharbaghi 1994; Mauboussin 2012; Zairi 1994). Consequently, the assessment of competitive advantage adopted for this research is based on nine questions divided into two groups of short-term and long-term performance indicators. These questions were not indented for the respondents to require the access and rights to share potentially confidential information based on hard data statements, as this would heavily reduce the number of finished interviews (Vij and Bedi 2016). Instead, the informants were asked to answer closed questions (yes/no), which enabled them to unambiguously position their companies towards the competitors 
or (when appropriate) dealt with easily observable nominal qualitative or quantitative progress in the last two years. This procedure might have created a potentially diversified group without making any sharp distinction between mediocre and underperforming companies. This was done deliberately, however, without any negative consequences for the research, because the questions on business performance were primarily designed to effectively filter the relatively small group of top-performing companies. The following descriptions were adopted as short-term performance indicators:

- the company has been steadily increasing sales or market share;

- the company has been steadily hiring more employees;

- the company has been steadily outcompeting other firms in terms of revenues;

- the company has taken over some of its competitors.

They describe a temporal success of a company, which may, but does not have to, have sustainable foundations. For example, increase in sales may be the knock-on effect of the accumulation of relationship capital, but may also be a result of extensive promotional programmes. Similarly, high revenues may have fundamental causes, but can also be influenced by some unimaginative direct cost reductions or shifts in how they are accounted and reported (Coyne 1986). The unexpected fall of numerous "Wall Street darlings" is the most striking evidence for this (Sterling 2002). In fact, short-term performance is a necessary but insufficient condition to label a company as having sustainable competitive advantage (Aaker 1989, Davis et al. 2000).

By contrast, the long-term indicators of competitive advantage reflect the positive effects of enduring relationships and strategic planning (Horovitz 1979; Schertzer et al. 2013). Customer-delighting encounters can be produced by accumulating and applying customer-specific knowledge through engaged employees (Sasser et al. 1997). Loyalty, whether of employees or customers, is an even more complex and constantly moving target, which reflects the organizational capability to manage internal and external interactions in a qualitative way time after time (Crosby and Johnson 2004). Thus, in line with models postulating sustainable performance measurement (e.g. Balanced Scorecard, Kaplan and Norton 1992; Performance Prism, Neely et al. 2002; SMART, Cross and Lynch 1988), 
long-term/sustainable competitive advantage is measured in this research by the following descriptive indicators:

- the company has been steadily outcompeting other firms in terms of customer satisfaction;

- the company has been steadily growing its loyal customer base;

- the company has been a sought-after employer.

Due to the reasons expounded in the Preface to this book and throughout Chap. 3, companies reporting both short-term and long-term competitive advantage characteristics are the central focus of this research. Later in the book, some of these will be described as having 'extremely strong competitive advantage', which translates into their having reported all the long-term and at least three out of four of the short-term competitive advantage descriptions. Three additional cohorts of companies will be presented in the background: companies with 'strong competitive advantage' are those that reported at least two short-term and two long-term descriptions; the label 'uncertain competitive advantage' characterizes companies that reported three descriptions (including no more than one long-term description); finally, the 'no competitive advantage' group consists of companies reporting no more than two short-term advantage descriptions.

According to the discussion on possible differences among companies in their ability to generate relational rents and on the system of RM midrange theories presented in Chap. 2, the overall impact of RM maturity on competitive advantage should be a stable effect. However, to potentially enrich the RM discourse and in line with research principle 3 defined in Chap. 3, the remaining questions in section $\mathrm{E}$ are aimed to additionally characterize the four cohorts of companies from different angles:

- economic sizes measured by the number of customers and the number of employees (the latter based on EU classification; Eurostat 2020a);

- market focus and business model;

- Polish Classification of Business Activities compliant with NACE rev.2 (Eurostat 2020b);

- organizational structure according to H. Mintzberg's typology (1993). 
An integral part of a questionnaire is its grading scale. In this study the informants were asked to assess to what extent the descriptions provided matched the realities of their companies on a 0-10 scale. If a score of ' 10 ' was chosen, the respondent assessed the given description as completely adequate to the situation in the company. Score ' 1 ' meant the opposite, and the other scores were to be applied as shades of intermediary situations. Score ' 0 ' could be used if the interviewed person was not knowledgeable in a particular field (McDaniel and Gates 2015).

The ten-point + ' 0 ' scale was deliberately chosen for several reasons. First, this scale usually achieves a higher explanatory power and thus a higher nomological validity than fewer-point scales, such as the sevenpoint Likert scale or even more so the popular five-point Likert scale (Coelho and Esteves 2007a, p. 334). Second, in odd-point scales the midpoint is typically used to reduce the response effort. This results in a fake distribution pattern, which overestimates the true frequency associated with this point (Coelho and Esteves 2007b, p. 549). Third, by having very clearly spread extremes, the ten-point scale seemed to be more capable of differentiating between truly and superficially relationship-oriented firms, which is in line with principle 4 of research design defined in Chap. 3. Moreover, the natural reference of a ten-point scale to the metric system, which is used in Poland, did not demand more effort from the respondents than the Likert odd-point scales. In accordance with E. Cox's guidelines based on information theory and the absolute judgement paradigm of psychophysics, ten response alternatives plus ' 0 ' seem to be refined enough to be capable of transmitting most of the information available from informants without unnecessarily encouraging response error (1980).

A related matter was the decision as to what score levels could be qualified as indicating RM maturity. Furthermore, would it be enough to reach the average or mean set at a particular level to qualify for further analysis, or would only descriptions which met a score at the minimum set level in every observation qualify? With reference to the fact that the descriptions used in the questionnaire are generally positive statements and given the articulated acute risk of collecting 'positive illusions' rather than objective facts (Martins and Kambil 1999), and thus the risk of mixing truly relationship-oriented companies with those who are only superficially devoted to RM (what was also reflected in the Hl tm theory-methodic hypothesis), it was decided to adopt a stringent qualification mechanism. Therefore, only descriptions rated 9 or 10 in every observation were made eligible as components of the RM maturity model. One can assume that these top 
answers are significantly less likely to be biased by wishful thinking as they clearly represent the 'positive extreme' associated with easily understandable $90-100 \%$ levels. By contrast, scores of 7 and 8 may still provide much comfort for those respondents who nurture their psychological needs by answering in an overly positive way.

This assumption is in line with empirical research, based on Net Promoter Score (NPS) methodology, which is a globally respected measure of customer prospective loyalty (Samson 2006; Schmidt-Subramanian et al. 2019). Its foundations were laid by F. Reichheld and his team at Bain \& Company, who managed to link customer declarations of product recommendations with actual referrals and purchasing history. However, this link appeared only to remain true if respondents reported $90-100 \%$ certainty. These customers generated $80 \%$ of referrals and were two times more likely to repurchase from the same company than customers reporting scores of 7-8 (Reichheld and Markey 2011, pp. 49-52). In other words, the demarcation line between what people merely declare and what really holds lies at score 9 , or $90 \%$ certainty.

Admittedly, NPS has also been criticized. Some researchers were not able to reproduce the causal link between NPS and revenue growth (Keiningham et al. 2007; Pingitore et al. 2007), albeit not using the same methodology and relying on third-party data (Whitlark and Rhoads 2011 ). Some have criticized its applicability across different cultures; however, they have failed to provide an adequate empirical refutation (Bendle and Bagga 2016). Others somewhat caustically referred to the title of F. Reichheld's original article in Harvard Business Review, "The one number you need to grow" (2003), and the simplicity of NPS, by invoking the limitations he had earlier personally indicated or eliminated (East et al. 2011; Fisher and Kordupleski 2019; Klaus and Maklan 2013; Grisaffe 2007). Some authors have even felt that F. Reichheld's alleged self-critique partly discredits his own work on customer loyalty (Sharp 2008). Nonetheless, NPS has been proved by other researchers to be a valid and stable customer behaviour predictor (Feehan et al. 2009; Samson 2006). Particularly important for the present research is that the same authors who criticize NPS simultaneously agree that the impact of customer satisfaction on the share of customer wallet and firms' revenues is sharply nonlinear (Keiningham et al. 2014).

This extensive comment on NPS is not only intended to advocate for the chosen interpretation of empirical results. It will also have an impact on the discussion on RM upper mid-range theory in Chap. 5. In fact, what 
F. Reichheld proposes to measure by NPS can be to some extent termed a highly aggregated RM capabilitys indicator. Moreover, some of its limitations can be mapped to the challenges in linking the RM business model and competitive advantage of a firm. However, first let us concentrate on the research methodology and the empirical results.

\subsection{Analytical Strategy}

The sampling universe consisted of the population of all Polish companies $(3,520,272$ entities $)$. The sample comprised 608 Polish firms stratified by the main industries according to the Polish Classification of Business Activities compliant with the EU industry standard classification. The stratification also covered company size (in terms of the number of employees). However, the sample deliberately does not truly reflect the population of Polish firms in this respect. According to the Polish Central Statistical Office, more than 96\% of registered companies in Poland employ 1-9 employees. As many as $95 \%$ of them are run by a single natural person, and in approximately $70 \%$ of cases as a form of self-employment (to avoid a tax burden imposed on formal employment). Moreover, 46\% of these one-man companies do not survive their first two years, and $69 \%$ close within five years of founding (PARP 2011, pp. 17, 49). Since, in this study, the focus is placed on the search of RM patterns of achieving sustainable competitive advantage, such ephemeral companies are not located at the heart of its research interest. Therefore, in terms of size, the sample was divided into almost four equally numerous cohorts (compare in the online appendix attached to this book).

The desired respondents were marketing, sales and HR managers, or in case of the smaller firms, their owners. One-man companies were not contacted at all. There were two pooling methods and three steps in the data collection procedure. To test the questionnaire before the main pooling stage started, the author of this book personally conducted eight direct interviews. The interlocutors were either executive board members or CRM project team members. As a result, some overlapping questions were removed or slightly rephrased to achieve more clarity. The primary data collection method was the Computer Assisted Telephone Interview (CATI), conducted by an external provider. The pooling procedure started with a pilot of 100 net interviews. Before the main group of records was collected, some additional minor amendments in order and wording of the questions were made to reduce the necessity for construing during an 
interview and the likelihood of misinterpretations of the substance of the asked questions. There were no significant differences between the levels of answers measured in any of the pooling stages. According to the statistics presented in Table 4.2, the response rate for this survey reached 13.1\%.

Despite all efforts of survey practitioners (introducing new communication channels, reminders and incentives, optimizing questionnaires) non-response is a persistent and impeding problem (Baruch 1999; Baruch and Holtom 2008; Hansen and Hurwitz 1946). However, a high nominal response rate should not be an end in itself. A survey that yields a low response rate can still do a fairly good job, if the effectively interviewed population is similar to the whole population from which it was originally drawn (Dillman 1991). The errors in survey coverage due to unit nonresponse can be compensated by applying weighting procedures (Dey 1997). Among various weighting methods, in this research, auxiliary information for the intended respondents was applied (Holt and Elliot 1991). Therefore, the sample design included the application of replacement samples to mimic the target population distribution in terms of industrial sectors and company size. To complete 600 telephone interviews, 9 replacement samples were needed. The whole process took only a few weeks; hence the time factor did not have an impact on the variance of results. In addition, the responses of the two halves of the dataset were compared. No significant differences between the variables were identified, which suggests that unit non-response bias is unlikely.

Item non-response mainly affected group B questions regarding ICT (e.g. CRM systems) and, to some extent, group D questions regarding departmental processes (e.g. nurturing online brand community). This is due to the number of companies that did not use any class of the surveyed ICT systems or did not manage the processes they were asked for. Usually data imputation is applied to prevent the reduction of sample size by

Table 4.2 Response statistics in CATI survey

\begin{tabular}{lc}
\hline Status & Quantity \\
\hline No phone connection & 721 \\
Refusal & 2726 \\
Postponed and not completed & 535 \\
Completed & 600 \\
Total & $\mathbf{4 5 8 2}$ \\
\hline
\end{tabular}

Source: CATI research agency Biostat 
discarding incomplete records from the analysis. However, data imputation works on an assumption of a random item non-response, which may produce another class of error (Gilley and Leone 1991). Also, in the case of this research the risk of heavily distorting the data patterns by the application of distance functions was too high. For example, illogical random similarities to CSR or HR might have been used to impute ICT governance. Post-stratification was also not applied, although this procedure is commonly used to adjust the sampling weights so that the estimated population sizes remain as they were in the stratified sample (Lumley 2011). In the subject dataset, however, none of the descriptive items affected by a relatively high non-response could potentially influence the final proposal of the RM maturity model, as they all scored too low to be qualified for further analysis. The distribution of missing data for all the questions is reported as ' 0 ' in the online appendix attached to this book.

The dominant method in quantitative empirical research on marketing and strategic management is the use of structural equation models (SEM; Chin et al. 2008; Shook et al. 2004). These are often built on a set of several questions of different granularity, which deal with more or less important business practices that are arbitrarily combined in several constructs directly or indirectly influencing the business results (Hair et al. 2012). The discussion or conclusions tend to comment on the statistical importance of the aggregated measure, while the outstanding activities are often listed only in the appendixes (if provided). In particular, although SEM can be used to systematically highlight the estimated strength of the relationships among assumed variables, the nature of these relationships and the actual ordering of the variables is always a matter of adopted convention (Bacharach 1989). Meanwhile, causal links between the variables may coexist with reciprocal ones, or some variables may only randomly correlate with important constructs (Scott 2002). Nonetheless, if the theory 'fits the data', the alternative explanations will typically not be analysed (Carter and Hodgson 2006). Meanwhile, approximately 75\% of SEMbased papers are reported to have at least one radically different equivalent model (Rong and Wilkinson 2011, p. 137). It is not surprising that quantitative research has been criticized as an impressive way of diminishing reality by providing 'exactly approximate' variables, averages and distributions (Gummesson 2017).

Given all the challenges in studying the RM maturity and owing to the fact that the H-D theory confirmation method does not provide selection criteria for choosing among analytically valid explanations of empirically 
captured phenomena (Ketokivi and Mantere 2010), instead of SEM-based inference this research applies machine learning techniques in the form of basket analysis/association rules mining. By harnessing sophisticated mathematical algorithms, these techniques offer simplicity and parsimony in data presentation without sacrificing the virtue of empirical adequacy (Hruschka 2019). The basic idea behind basket analysis/association rules mining can be best related to the dilemma of a retailer. If a customer buys product $\alpha$ and product $\beta$, how likely is it that they will be interested in buying product $\gamma$ ? Provided there is evidence in the data for some kind of rule linking $\alpha, \beta, \gamma$ and more complicated variables containing sets of products, a retailer might find a key to successfully promote a basket of products that the given customer is likely to purchase as a bundled offer. The method is also suitable for the analysis of complex phenomena such as multilevel processes involving micro (e.g. organizational behaviour) and macro (organizational strategy) variables (Aguinis et al. 2013). The same applies to rules linking RM activities and the approaches of highly successful companies.

Let $I=\{i 1, i 2, \ldots, i k\}$ be a set of $k$ binary attributes called items, where $k$ denotes the number of attributes.

In a set of transactions (answers to questions), each transaction contains a subset of $I$, marked by an individual respondent's identifier.

Let $T j=\{t 1, t 2, \ldots, t n\}$, where $T j \in=I$ is a set of transactions, where $n$ denotes the number of respondents.

Basket analysis focuses on finding non-trivial patterns within the answers of respondents, which are defined as:

$$
A \Rightarrow B
$$

where $\mathrm{A}, \mathrm{B} \in I$ and $\mathrm{A} \cap \mathrm{B}=\varnothing$. The subset of items $\mathrm{A}$ is called antecedent (left-hand side-LHS) and the subset of items B is called consequent (right-hand side-RHS). The symbol $\Rightarrow$ indicates the rule linking the item sets.

Unlike in the case of SEM, where it would be necessary to build an ex ante model assuming the existence of relationships between items aggregated to a limited number of variables and constructs, the adopted method made it possible to avoid biasing the results of statistical inference with a predefined vision of what the final RM maturity model should look like. Certainly, the applied questionnaire does also entail a vision of what activities and approaches may characterize an RM-mature company. However, 
it is proposed as the preliminary model, a wide palette of options, which could be only partly relevant and relatively freely intertwined without any harm to the final model. In this sense this research has an exploratory character.

Another advantage is the freedom in defining target variables (different levels of competitive advantage) as combinations of questions self-reported by the respondents, without having to assume any latent variable(s) that might be measured by their answers. Instead, the focus was placed on uncovering hidden complex relationships between the descriptive variables in an intuitive way that can be easily communicated to wider audiences (Aguinis et al. 2010). Moreover, the multiple-choice questions concerning different company characteristics (including the question on competitive advantage) are based on a nominal measuring scale, and the 40 descriptive questions incorporate a ten-point interval scale supplemented by an additional ' 0 ' answer. This limits the applicability of classic SEM inference, which requires at least the use of ordinal scales. Basket analysis/association rules work well even with weak scales and allow item non-response without having to take the risk of data imputation (Aguinis et al. 2013; Aumann and Lindell 2003).

Finally, the computed rules can be easily quality controlled by the use of several notations. This is of particular importance in large databases, as in a dataset consisting of $k$ items, the square of $k$ combinations is possible. Therefore, following Hornik et al. and Hahsler $(2005$; 2011$)$, three notations were introduced: support, confidence and lift.

Support is the frequency of transactions containing all the items in both item subsets A and B. In other words, support denotes the probability of simultaneously observing $\mathrm{A}$ and $\mathrm{B}$ in the dataset.

$$
A \Rightarrow B=P(A \cap B)=\frac{n(A \cap \mathrm{B})}{N .}
$$

where $N$ is the total number of all transactions and $n(x)$ is the number of transactions containing $\mathrm{x}$.

In this research the minimum support was set to 0.5 , which means that any of the presented rules will appear in at least $50 \%$ of transactions.

Confidence indicates how often a particular rule has been found to be true. In other words, confidence denotes the conditional probability of observing the RHS of the rule in transactions that also include the LHS 
selected in the first place. This can be assessed through the proportion of supports:

$$
A \Rightarrow B=P(B \mid A)=\frac{n(A \cap \mathrm{B})}{n(A)}
$$

where $n(x)$ is the number of transactions containing $\mathrm{x}$.

In this research the minimum confidence was set to 0.9 , which means that any of the rules will appear true in at least $90 \%$ of instances they apply to.

Lift represents the ratio of the observed support to that to be expected if $\mathrm{A}$ and $\mathrm{B}$ were independent. If the antecedent and the consequent that build a rule are dependent on one another, lift should be greater than 1 . In other words, lift indicates the probability of selecting B if A was selected.

$$
A \Rightarrow B=\frac{(\text { confidence })}{P(B)}=\frac{P(B \mid A)}{P(B)}
$$

In this research the minimum lift was set to 1.25 , which means that any of the rules will imply the increase in probability of co-occurrence of its antecedent and consequent by at least $25 \%$.

With reference to the discussed theoretical assumptions and the adopted bias reduction strategy, the association rules mining procedure concentrates entirely on the companies reporting 9- or 10-rated relational activities and approaches, and thus mainly on the 'extremely strong competitive advantage' group. Therefore, before the actual statistical analysis started, each of the 40 descriptive questions incorporated in the preliminary RM maturity model were coded according to the following rule:

$$
i k=\left\{\begin{array}{c}
1 \text { if } Q k \in\{9,10\} \\
0 \text { otherwise }
\end{array}\right.
$$

where $Q k$ designates the original answers from the respondents to question $k$ and notes that possible values were $\mathrm{Qk} \in\{1, \ldots, 10)$. Only variables denoted by $i k$ were further analysed within the group of companies with 'extremely strong competitive advantage'. This allowed the analysis to be narrowed down to items that may have the highest impact on RM maturity. 


\subsection{The Empirical Results on RM Maturity and Competitive Advantage}

The statistical analysis of the empirical material was powered by the ' $R$ ' system enhanced by the packages 'arules' and 'arulesViz', which facilitate mining and visualization of association rules and frequent item sets. Table 4.3 shows the share and number of companies in the dataset characterized by different levels of competitive advantage.

Before presenting the actual rules, some introductory descriptive statistics will be analysed. Figure 4.1 shows a regular ascending tendency across all RM maturity characteristics (small grey dots), in the overall means (big grey dots in the boxes), quartiles 1 and 3 (the bottom/upper parts of the boxes), and medians (the black lines in the boxes) in relation to the competitive advantage achieved. In addition, Fig. 4.2 depicts the differences between the companies having 'extremely high competitive advantage' and the 'no competitive advantage' group in each and every factor. Both figures indicate that the companies with 'extremely high competitive advantage' had higher mean scores for almost every item. The only notable exceptions are a few items from group B (ICT systems). Nonetheless, these differences are small (no more than 3.7\%), and the overall average score level of all group B items is the lowest in the pool. Therefore, they must be playing only a background role in achieving competitive advantage.

These findings are of particular importance with regard to the relatively small number of companies with 'extremely high competitive advantage' in the analysed sample. For obvious reasons, top-performing companies are always scarce in the population of business entities, whenever competitive advantage or (as it seems based on this data) RM maturity is concerned. Therefore, it is important that the concept of RM maturity based on association rules computed in this small group is also indirectly justified by the trends observed in the whole dataset.

Table 4.3 Companies of different competitive advantage in the dataset

\begin{tabular}{lcc}
\hline Competitive advantage & Share of companies (\%) & Number of companies \\
\hline Extremely strong & 4 & 24 \\
Strong & 15 & 92 \\
Uncertain & 13 & 76 \\
None & 68 & 416 \\
\hline
\end{tabular}




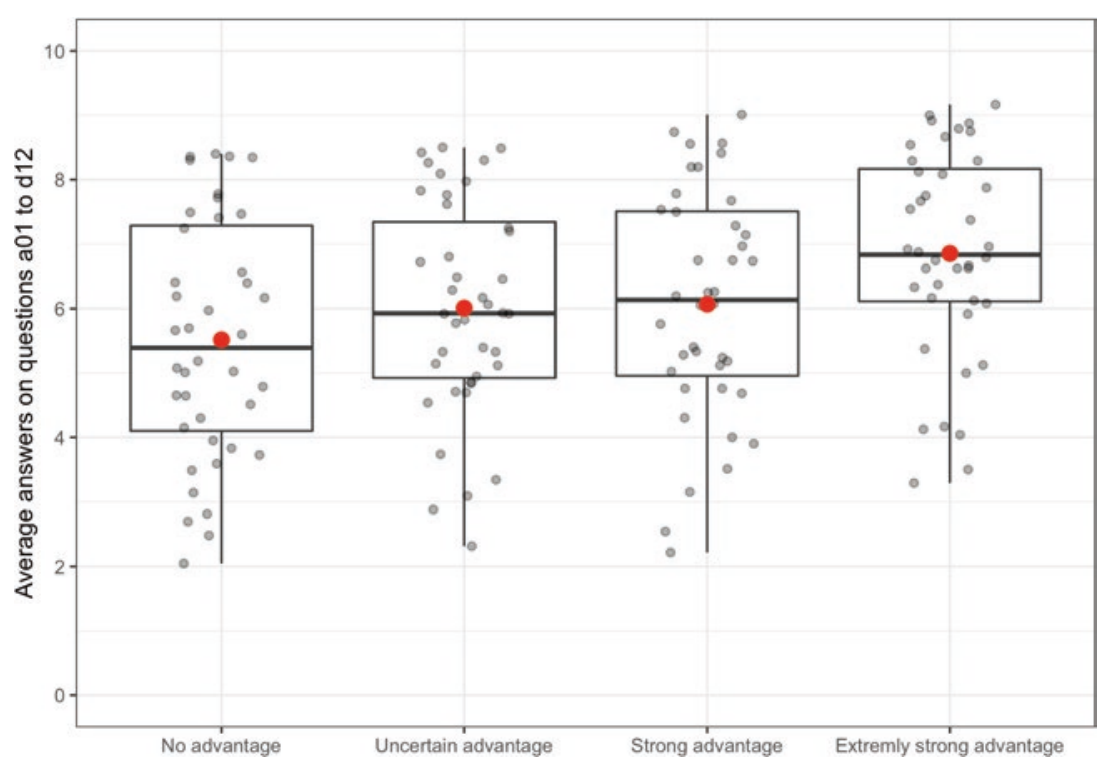

Fig. 4.1 Mean results for every item in the dataset broken down by competitive advantage groups

The legitimacy of the elaborated results based only on the 'extremely high competitive advantage' group of firms could also be potentially questioned, if this group were to reveal some important characteristics other than proficiency in distinct RM activities and approaches and the highest level of competitive advantage. Figure 4.3 condenses the information on the four clusters of companies based on their questionnaires' section $\mathrm{E}$ characteristics. The first impression is that the companies with at least some elements of the competitive advantage compound are in many aspects much more comparable than the 'no competitive advantage' group of companies. They tend to be larger and more likely to have numerous clients and employees. By contrast, the most significant peculiarity of the 'extremely strong competitive advantage' group of companies is its dominant $\mathrm{B} 2 \mathrm{~B}$ focus. This, however, does not come as a surprise as RM originates in industrial marketing (Payne and Frow 2017), and CRM is technically easier to facilitate in contractual markets (Deszczyński 2008).

Concerning the declared business model and the main industry, the top-performing companies report activities in all three major business 


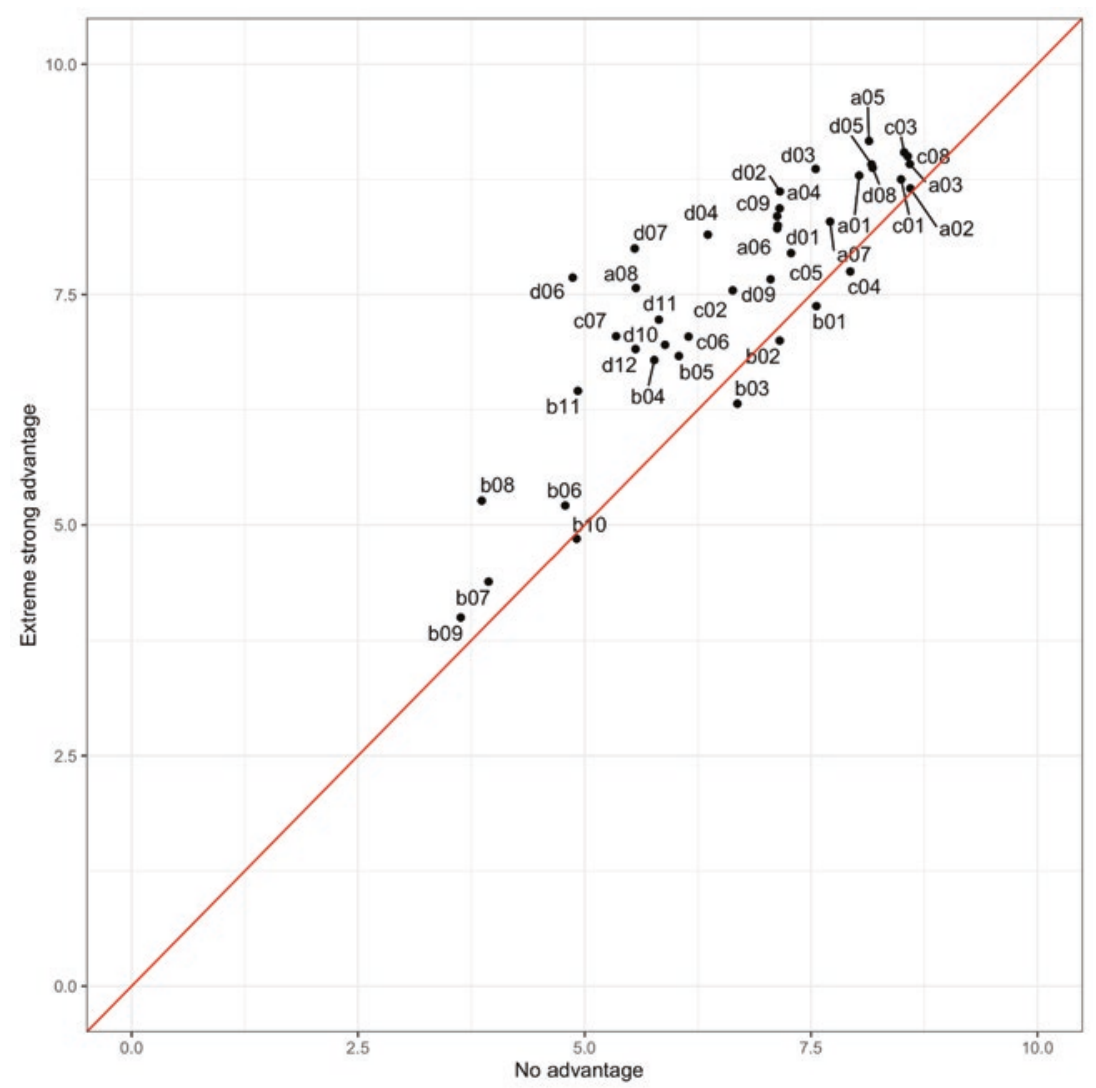

Fig. 4.2 Comparison of differences in the mean results between the 'extremely high competitive advantage' and 'no competitive advantage' groups of companies

domains, production, commerce and services, which confirms the findings of Reinartz et al. (2004), who insist that CRM benefits do not vary significantly across industries. Notably, and in line with the SDL, the greatest share among these companies were those who declared organizing a complex chain of value creation (services or production and commerce structures, customer service, and augmented services). Interestingly, all groups of companies are relatively comparable in terms of organizational structure according to H. Mintzberg's typology (1993). Although by having a stronger profile of small entities, the 'no competitive advantage group' of 


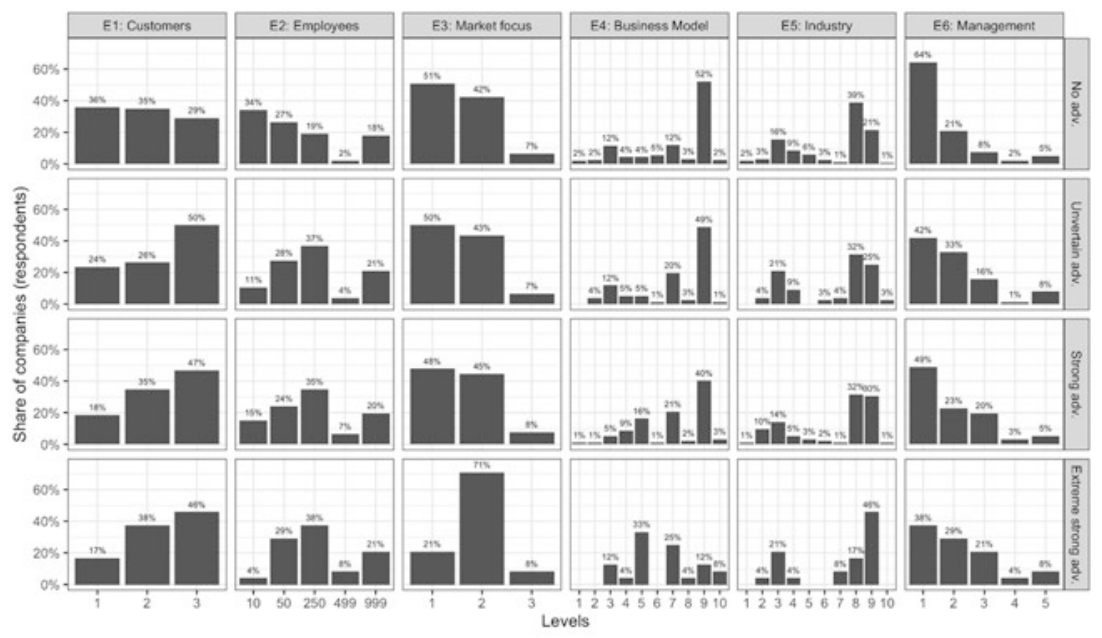

Fig. 4.3 Companies' characteristics across groups of achieved competitive advantage. Note: For decoding the results on the $\mathrm{X}$ axis, please refer to section $\mathrm{E}$ of the questionnaire

companies stands out with its proportion of 'strong leadership and centralization' type. Nonetheless, given other similarities, the organizational structure seems not to have a decisive impact on the likelihood of achieving sustainable competitive advantage. To sum up, the 'extremely high competitive advantage' group of companies remains diversified and relatively similar to other groups of companies, with only a few notable but logical differences. This is in line with the conclusions of other researchers who did not find any significant differences in industry type and commoditization among companies achieving relationally based competitive advantage (Coviello et al. 2002; Sharma and Iyer 2007; Reimann et al. 2010). Therefore, what these companies achieve in terms of RM maturity is valid and potentially transferable to all entities, and thus these results are generalizable. Hence, the identified set of association rules computed for the group of companies with 'extremely strong competitive advantage' can be viewed as representing a bundle of capabilities that forms a critical mass of proficiency in RM and foretells a sustainable competitive advantage.

Table 4.4 contains a list of rules, with the level of notations and the number of companies with these rules identified. Figure 4.4 visualizes the 
Table 4.4 Association rules computed for the 'extremely strong competitive advantage' group of companies

\begin{tabular}{llllcccc}
\hline Rule & LHS & & RHS & Count & Support & Confidence & Lift \\
\hline 1 & A06 & $\Rightarrow$ & A05 & 12 & 0.52 & 1.00 & 1.25 \\
2 & C01 & $\Rightarrow$ & C03 & 12 & 0.52 & 1.00 & 1.53 \\
3 & C01 & $\Rightarrow$ & C08 & 12 & 0.52 & 1.00 & 1.53 \\
4 & A02 & $\Rightarrow$ & D05 & 12 & 0.52 & 0.92 & 1.42 \\
5 & A02 & $\Rightarrow$ & C03 & 12 & 0.52 & 0.92 & 1.42 \\
6 & A04 & $\Rightarrow$ & C08 & 12 & 0.52 & 0.92 & 1.42 \\
7 & C03 & $\Rightarrow$ & C08 & 12 & 0.61 & 0.93 & 1.43 \\
8 & C08 & $\Rightarrow$ & C03 & 12 & 0.61 & 0.93 & 1.43 \\
9 & C01, C03 & $\Rightarrow$ & C08 & 12 & 0.52 & 1.00 & 1.53 \\
10 & C01, C08 & $\Rightarrow$ & C03 & 12 & 0.52 & 1.00 & 1.53 \\
11 & C03, D03 & $\Rightarrow$ & C08 & 12 & 0.52 & 1.00 & 1.53 \\
12 & C08, D03 & $\Rightarrow$ & C03 & 12 & 0.52 & 1.00 & 1.53 \\
13 & C03, D05 & $\Rightarrow$ & C08 & 12 & 0.52 & 0.92 & 1.42 \\
14 & C08, D05 & $\Rightarrow$ & C03 & 12 & 0.52 & 1.00 & 1.53 \\
15 & C03, D08 & $\Rightarrow$ & C08 & 12 & 0.52 & 1.00 & 1.53 \\
16 & C08, D08 & $\Rightarrow$ & C03 & 12 & 0.52 & 0.92 & 1.42 \\
\hline
\end{tabular}

Note: For decoding the LHS and RHS, please refer to sections A, C and D of the questionnaire provided in Table 4.1. Count represents the number of companies for which the particular rule was reported. By coincidence, for every rule it equals 12 , but the set of companies reporting the rules differs in every case.

same results in a network structure highlighting multifaceted associations between the items. Thus, the task of verifying the elements that constitute the final proposal of the RM maturity model (empirically validated successful RM business model) is completed.

What is worth noting is that the association rules based on $9 / 10$ scores could only be computed among the top-performing companies, whereas the differences between the means of the top-performing and underperforming companies on average reached no more than $30 \%$, and in most cases around $10 \%$. The only exception was a single rule identified in the group of companies with 'strong competitive advantage' linking items $\mathrm{C} 01$ and $\mathrm{C} 03$. However, the same rule (R2) was also reported for the companies with 'extremely strong competitive advantage'. This observation not only directly validates the $\mathrm{R} 2$ rule, but also matches the reported correlation of ascending levels of competitive advantage and RM maturity. Hence, the discovered rules do not appear to be an accidentally isolated effect but rather indicate a non-linear regularity. 

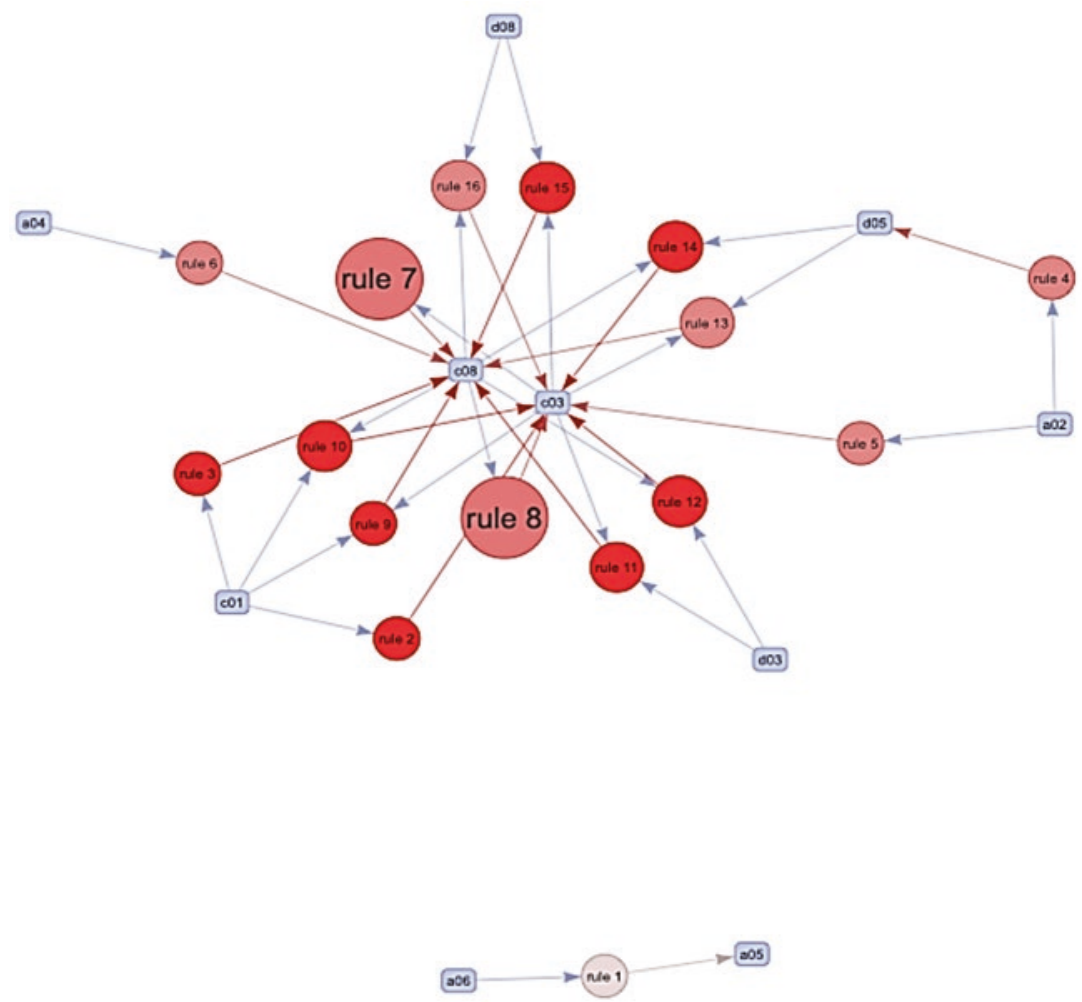

Fig. 4.4 The network of association rules. Note: For decoding the item subsets composing the rules, please refer to sections $\mathrm{A}, \mathrm{C}$ and $\mathrm{D}$ of the questionnaire

The first impression after analysing the basket containing the RM activities and approaches marked by the association rules is that both RM maturity and sustainable competitive advantage correlate with ethics. Thirteen out of sixteen rules linking distinctive RM characteristics, reported by market leaders, include items which directly deal with collaboration, fairness, openness and respect. The strongest rules supplied in the analysis (R7 and R8) include two reciprocally correlated items (C03 and $\mathrm{C} 08$ ): the promotion of positive values and attitudes of the company creates a working ambience, which supports communication and cooperation, and in turn, good communication and cooperation (regardless of 
structure and hierarchy) contribute to the perception of corporate efforts to instil positive values and attitudes as meaningful and sincere. At the same time, an ethical company does not seem to be necessarily concentrating on its external stakeholders, but rather it starts by taking care of the well-being of its own employees (note that item C07 concerning CSRlabelled engagement did not qualify for any of the top rules).

A good working ambience coincidences with a positive perception of company leadership, and in an even stronger way it emphasizes the internal nature of RM maturity. Rules $\mathrm{R} 2$ and $\mathrm{R} 3$, as well as rules $\mathrm{R} 9$ and $\mathrm{R} 10$, which incorporate items $\mathrm{C} 01, \mathrm{C} 03$ and $\mathrm{C} 08$, reinforce this view by emphasizing the importance of authentic leadership based on professionalism, a sense of responsibility (subsidiarity to employees) and an admirable moral stance. It seems that, regardless of times and social context, people need leaders, and they adjust their attitudes towards leader-sponsored ventures according to the trust and engagement they cultivate. In this context leadership and management skills, including the ability to balance the everpresent pressure for short-term profits with the investment of time and money in an employee-friendly working environment, advance to a central point in the top management's agenda (Chmielecki and Sułkowski 2018). It seems also that a basic tool of leadership (aside from someone being a living example of right behaviour) is open communication (the willingness and ability to listen to and discuss peoples' ideas, expectations and problems).

Rules R4 and R5 include the third ethical item (A02), which presents an official rooting of ethical behaviour in a corporate strategy. The link between this declaration and the actual behaviour in R5 is clear. By contrast, $\mathrm{R} 4$ requires a deeper reflection, as it links the composite of ethics with the dominant role of direct communication with customers. However, it seems that the ethical approach to business creates an environment for communication which is both meaningful for customers and beneficial for the company (e.g. in terms of marketing conversions). Known as extreme customer-centricity or customer value-based organizational culture, this means, rather than spamming customers with remote offers, educating them about the impact of their choices on community and society and making sure no customer makes a mistake or overlooks some benefit (Peppers and Rogers 2013; Sheth 2017). In other words, being ethical also means that the companies have something relevant to say to their individual customers/business partners that can be most effectively communicated in a one-to-one interaction. The ethical issues, partnership 
cooperation and good communication go hand-in-hand in the pairs of rules $\mathrm{Rl} 1$ and $\mathrm{Rl} 2, \mathrm{Rl} 3$ and $\mathrm{Rl4}$, and $\mathrm{Rl} 5$ and Rl6, where they change positions as LHS and RHS, accompanied by processual D-type items: D03, D08 and D05. In terms of D05, again the link between fairness and a good working climate and the ability to communicate relevantly is reinforced. The other items also deal with communication, but in a more specific context of lead management (D03) and customer feedback analysis (D08).

Regrettably, lead management is quite a rare subject of scientific examination. However, in the author's own research conducted across several industries in Poland, a catastrophic underperformance in managing leads was reported, marked by an average $30 \%$ loss of prospective buyers only because companies failed to give any answer to customers' enquiries (Deszczyński 2016; Deszczyński and Mielcarek 2014). Although many tactical answers could partly explain such poor performance, the roots of this problem most likely lie in the hands of top management, who created a working environment of disengagement (Bonner et al. 2016; Kelleher 2011). To make matters worse, if companies are not able to partner in a dialogue with their customers at a point so close to sales, an even poorer performance can be expected elsewhere, particularly when customers report dissatisfaction. Hence, according to rules Rl1, Rl2, Rl5 and Rl6, lead management and customer feedback analysis can act as a relatively easy way to capture indicators reflecting the degree of a company's RM maturity.

The ability of a company to manage relationships with non-customer external stakeholders is reflected in rule R6. It directly links items A04 and $\mathrm{C} 08$, which means that the ability to holistically assess, for example, the role of a supplier in a total-cost-of-ownership perspective indicates a good internal working culture. In a business practice, this can mean that, for example, a purchasing department's focus is not only placed on traditional short-term savings, but it also takes into account the quality or logistical issues important for other departments (Kahkonen and Lintukangas 2018).

Finally, rule Rl links the ability to purposefully manage relationships with all direct customers of a company (A06) to the ability to do this selectively towards the very best of them (A05). It looks like a remote phenomenon detached from the network of the other 15 rules (compare Fig. 4.4). However, assessed from the perspective of the ability to effectively communicate, represented by the focal $\mathrm{C} 03$ and $\mathrm{C} 08$ items, it perfectly 
complements the whole picture of mature RM orientation. In addition, among all the others, item A06 reached the highest mean score (9.17) and quartile 1 score (8.75), which positions the selective individualization of relationship management (distinct from ICT-powered mass customization efforts) as a central characteristic of a mature relationship-oriented company.

Although the fact that not all of the RM dimensions contribute equally to business performance was evidenced in the literature (Pozza et al. 2018), what comes as something of a surprise is the total absence of technological issues in the final proposal of the RM maturity model. Moreover, top-performing companies scored slightly worse on some of the ICTrelated items, with B03 (referring to a central customer data warehouse) as the most striking example (the average of top-performing companies was $3.7 \%$ below the average of poor performers). This does not mean companies can do away with ICT tools. The global COVID-19 crisis has shown that modern communication technology is a vital aspect for every business, whether internal or external communication is concerned. However, it seems that ICT plays a secondary, supporting role, facilitating the way to success for companies that have already mastered $\mathrm{RM}$ as a predominately human-to-human concept. Owing to the fact that this research was conducted before the outbreak of the COVID-19 crisis, some additional comments concerning ICT issues are offered in the Final Note.

Although not included in the list of the strongest rules, the position of items A08, D06 and D07 is also worth noting. On average, all of them scored no more than 8.0 and no more than half of the scores were $9 \mathrm{~s}$ or 10s, but they exhibit the largest (more than 2 points on average) distance between the companies with 'extremely strong competitive advantage' and the 'no competitive advantage' group. This may mean that they are particularly challenging, also for the best companies, even if from a benchmarking point of view they do a good job. However, for whatever reason the current level of competition does not necessitate more performance in these respective areas, so they can be seen as additional key factors of RM competence in the future. Moreover, describing a part of the customer interface, items D06 and D07 may potentially complement items D03 and D08 as relatively easy to capture and test indicators of RM maturity. All of them seem to be putting the coordination of CRM activities to a real test.

Although the empirical research validates and refines the RM maturity model and provides substance to formulate reasonable guidelines for its successful implementation, the very concept, like any H-D framework, 
only explains the selected realm of business reality. While company characteristics provided in group $\mathrm{E}$ of the questionnaire generally showed that the RM maturity model is not discriminatory towards any particular industry, company size or even management style, some unidentified internal or external factors may have influenced the ability of some companies to capitalize on their relationship portfolio. Hence, there are questions that need to be further discussed. In particular, why is achieving RM-based sustainable competitive advantage largely a game of all or nothing? In the end, $70 \%$ or $80 \%$ performance is still a fairly good result. And how is it possible that RM-immature firms could ever survive facing the competition of their truly RM-oriented rivals? These and other issues cannot be addressed by the RM maturity model alone, but need a wider perspective offered by the discussion on the RM upper mid-range theory conducted in the next and final chapter.

\section{REFERENCES}

Aaker, David A. 1989. Managing Assets and Skills: The Key to a Sustainable Competitive Advantage. California Management Review 31 (2): 91-106. https://doi.org/10.2307/41166561.

Adèr, Hermanus Johannes. 2008. Advising on Research Methods: A Consultant's Companion. Huizen: Johannes van Kessel Publishing.

Aguinis, Herman, Steve Werner, JéAnna Lanza Abbott, Cory Angert, Joon Hyung Park, and Donna Kohlhausen. 2010. Customer-Centric Science: Reporting Significant Research Results With Rigor, Relevance, and Practical Impact in Mind. Organizational Research Methods 13 (3): 515-539. https://doi. org $/ 10.1177 / 1094428109333339$.

Aguinis, Herman, Lura E. Forcum, and Harry Joo. 2013. Using Market Basket Analysis in Management Research. Journal of Management 39 (7): 1799-1824. https://doi.org/10.1177/0149206312466147.

Alvesson, Mats, and Stanley Deetz. 2000. Doing Critical Management Research. London: SAGE.

Alvesson, Mats, and Kaj Sköldberg. 2009. Reflexive Methodology: New Vistas for Qualitative Research. London: SAGE.

Alwin, Duane F. 2007. Margins of Error: A Study of Reliability in Survey Measurement. Hoboken: John Wiley \& Sons.

Aumann, Yonatan, and Yehuda Lindell. 2003. A Statistical Theory for Quantitative Association Rules. Journal of Intelligent Information Systems 20 (3): 255-283. https://doi.org/10.1023/A:1022812808206. 
Bacharach, Samuel B. 1989. Organizational Theories: Some Criteria for Evaluation. The Academy of Management Review 14 (4): 496-515. https://doi. org $/ 10.2307 / 258555$.

Baruch, Yehuda. 1999. Response Rate in Academic Studies-A Comparative Analysis. Human Relations 52 (4): 421-438. https://doi. org/10.1177/001872679905200401.

Baruch, Yehuda, and Brooks C. Holtom. 2008. Survey Response Rate Levels and Trends in Organizational Research. Human Relations. https://doi. org/10.1177/0018726708094863.

Bendle, Neil T., and Charan K. Bagga. 2016. The Metrics That Marketers Muddle. MIT Sloan Management Review 57 (3): 73-82.

Biemer, Paul P. 2010. Total Survey Error: Design, Implementation, and Evaluation. Public Opinion Quarterly 74 (5): 817-848. https://doi.org/10.1093/ $\mathrm{poq} / \mathrm{nfq} 058$.

Bonner, Julena M., Rebecca L. Greenbaum, and David M. Mayer. 2016. My Boss Is Morally Disengaged: The Role of Ethical Leadership in Explaining the Interactive Effect of Supervisor and Employee Moral Disengagement on Employee Behaviors. Journal of Business Ethics 137 (4): 731-742. https://doi. org/10.1007/s10551-014-2366-6.

Carter, Richard, and Geoffrey M. Hodgson. 2006. The Impact of Empirical Tests of Transaction Cost Economics on the Debate on the Nature of the Firm. Strategic Management Journal 27 (5): 461-476. https://doi. org/10.1002/smj.531.

Chandra, Yanto, and Ian F. Wilkinson. 2017. Firm Internationalization from a Network-Centric Complex-Systems Perspective. Journal of World Business 52 (5): 691-701. https://doi.org/10.1016/j.jwb.2017.06.001.

Chin, Wynne W., Robert A. Peterson, and Steven P. Brown. 2008. Structural Equation Modeling in Marketing: Some Practical Reminders. Journal of Marketing Theory and Practice 16 (4): 287-298. https://doi.org/10.2753/ MTP1069-6679160402.

Chmielecki, Michał, and Łukasz Sułkowski. 2018. Cultural Factors of Trust in a Public Organization as a Workplace. In Managing Public Trust, ed. Barbara Koěuch, Sławomir J. Magala, and Joanna Paliszkiewicz, 99-1 14. Cham: Springer International Publishing. https://doi.org/10.1007/978-3-319-70485-2_7.

Clarke, Irvine. 2001. Extreme Response Style in Cross-cultural Research. International Marketing Review 18 (3): 301-324. https://doi.org/ 10.1108/02651330110396488.

Coelho, Pedro S., and Susana P. Esteves. 2007a. The Choice between a Fivepoint and a Ten-Point Scale in the Framework of Customer Satisfaction Measurement. International Journal of Market Research 49 (3): 313-39. https://doi. org/10.1177/147078530704900305. 
Coelho, Pedro S., and Susana P. Esteves. 2007b. Correspondence Regarding "The Choice between a Five-Point and a Ten-Point Scale in the Framework of Customer Satisfaction Research", by Pedro S. Coelho and Susana P. Esteves. International Journal of Market Research 49 (5): 547-49.

Coviello, Nicole E., Roderick J. Brodie, Peter J. Danaher, and Wesley J. Johnston. 2002. How Firms Relate to Their Markets: An Empirical Examination of Contemporary Marketing Practices. Journal of Marketing 66 (3): 33-46. https://doi.org/10.1509/jmkg.66.3.33.18500.

Cox, Eli P. 1980. The Optimal Number of Response Alternatives for a Scale: A Review. Journal of Marketing Research 17 (4): 407-422. https://doi. org/10.1177/002224378001700401.

Coyne, Kevin P. 1986. Sustainable Competitive Advantage-What It Is, What It Isn't. Business Horizons 29 (1): 54.

Crosby, Lawrence A., and Sheree L. Johnson. 2004. The Three Ms of Customer Loyalty. Marketing Management 13 (4): 12-13.

Cross, Kelvin, and Richard Lynch. 1988. The "SMART" Way to Define and Sustain Success. National Productivity Review 8 (1): 23-33.

Crowne, Douglas P., and David Marlowe. 1960. A New Scale of Social Desirability Independent of Psychopathology. Journal of Consulting Psychology 24 (4): 349-354. https://doi.org/10.1037/h0047358.

Czakon, Wojciech. 2015. Podstawy metodologii badan w naukach o zarzadzaniu. 3rd ed. Ed. Wojciech Czakon. Warszawa: Oficyna a Wolters Kluwer business. https://ruj.uj.edu.pl/xmlui/handle/item/85236

Davidson, Karina, and Michael William MacGregor. 1998. A Critical Appraisal of Self-Report Defense Mechanism Measures. Journal of Personality 66 (6): 965-992. https://doi.org/10.1111/1467-6494.00039.

Davis, James H., F. David Schoorman, Roger C. Mayer, and Hwee Hoon Tan. 2000. The Trusted General Manager and Business Unit Performance: Empirical Evidence of a Competitive Advantage. Strategic Management Journal 21 (5): 563-576. https://doi.org/10.1002/(SICI)1097-0266(200005)21:5<563:: AID-SMJ99>3.0.CO;2-0.

De Jong, Martijn G., Jan-Benedict E.M. Steenkamp, Jean-Paul Fox, and Hans Baumgartner. 2008. Using Item Response Theory to Measure Extreme Response Style in Marketing Research: A Global Investigation. Journal of Marketing Research 45 (1): 104-115. https://doi.org/10.1509/ jmkr.45.1.104.

Deszczyński, Bartosz. 2008. Zewnętrzne Bariery Wdraěania Strategii CRM w Integrującej Się Europie. In Polityka Unijnej Integracji: Wybrane Relacje Zewnętrzne $i$ Wewnętrzne, 361-376. Zielona Góra: Uniwersytet Zielonogórski. - 2016. The Maturity of Corporate Relationship Management. Gospodarka Narodowa 283 (3): 73-104. https://doi.org/10.33119/GN/100777. 
Deszczyński, Bartosz, and Paweł Mielcarek. 2014. The Online/Offline Gap in Lead Management Process. Przegląd Organizacji 8: 42-49. https://doi. org/10.33141po.2014.08.07

Dey, Eric L. 1997. Working with Low Survey Response Rates: The Efficacy of Weighting Adjustments. Research in Higher Education 38 (2): 215-227. https://doi.org/10.1023/A:1024985704202.

Dillman, Don A. 1991. The Design and Administration of Mail Surveys. Annual Review of Sociology 17 (1): 225-249. https://doi.org/10.1146/annurev. so.17.080191.001301.

Donaldson, Stewart I., and Elisa J. Grant-Vallone. 2002. Understanding SelfReport Bias in Organizational Behavior Research. Journal of Business and Psychology 17 (2): 245-260. https://doi.org/10.1023/A:1019637632584.

Dörnyei, Zoltán, and Tatsuya Taguchi. 2009. Questionnaires in Second Language Research: Construction, Administration, and Processing. Routledge. https:// doi.org/10.4324/9780203864739.

East, Robert, Jenni Romaniuk, and Wendy Lomax. 2011. The NPS and the ACSI: A Critique and An Alternative Metric. International Journal of Market Research 53 (3): 327-346. https://doi.org/10.2501/IJMR-53-3-327-346.

Eurostat. 2020a. Small and Medium-Sized Enterprises (SMEs) - Eurostat. https://ec.europa.eu/eurostat/web/structural-business-statistics/structuralbusiness-statistics/sme

- 2020b. Europa - RAMON - Classification Detail List. https://ec.europa. $\mathrm{eu} /$ eurostat/ramon/nomenclatures/index.cfm? TargetUrl=LST_NOM_ DTL\&StrNom=NACE_REV2\&StrLanguageCode $=$ PL\&IntPcKey $=\&$ StrLayo utCode=HIERARCHIC

Feehan, Michael, Cristina Ilangakoon, and Penny Mesure. 2009. Keeping Score. Marketing Research 21 (4): 6-10.

Feurer, Rainer, and Kazem Chaharbaghi. 1994. Defining Competitiveness: A Holistic Approach. Management Decision 32 (2): 49-58. https://doi. org/10.1108/00251749410054819.

Fisher, Nicholas I., and Raymond E. Kordupleski. 2019. Good and Bad Market Research: A Critical Review of Net Promoter Score. Applied Stochastic Models in Business and Industry 35 (1): 138-151. https://doi.org/10.1002/ asmb.2417.

Foddy, William H. 1994. Constructing Questions for Interviews and Questionnaires: Theory and Practice in Social Research. Cambridge: Cambridge University Press.

Gilley, Otis W., and Robert P. Leone. 1991. A Two-Stage Imputation Procedure for Item Nonresponse in Surveys. Journal of Business Research 22 (4): 281-291. https://doi.org/10.1016/0148-2963(91)90035-V.

Grisaffe, Douglas B. 2007. Questions About the Ultimate Question: Conceptual Considerations in Evaluating Reichheld's Net Promoter Score (NPS). Journal of Consumer Satisfaction, Dissatisfaction and Complaining Behavior 20: 36-53. 
Gummesson, Evert. 2017. From Relationship Marketing to Total Relationship Marketing and Beyond. Journal of Services Marketing 31 (1): 16-19. https:// doi.org/10.1108/JSM-11-2016-0398.

Hahsler, Michael, Sudheer Chelluboina, Kurt Hornik, and Christian Buchta. 2011. The Arules R-Package Ecosystem: Analyzing Interesting Patterns from Large Transaction Data Sets. Journal of Machine Learning Research 12 (June): 2021-2025.

Hair, Joseph F., Marko Sarstedt, Torsten M. Pieper, and Christian M. Ringle. 2012. The Use of Partial Least Squares Structural Equation Modeling in Strategic Management Research: A Review of Past Practices and Recommendations for Future Applications. Long Range Planning, Analytical Approaches to Strategic Management: Partial Least Squares Modeling in Strategy Research, 45 (5): 320-340. https://doi.org/10.1016/j. lrp.2012.09.008.

Hansen, Morris H., and William N. Hurwitz. 1946. The Problem of NonResponse in Sample Surveys. Journal of the American Statistical Association 41 (236): 517-529. https://doi.org/10.1080/01621459.1946.10501894.

Helgeson, James G., and Magne Supphellen. 2004. A Conceptual and Measurement Comparison of Self-Congruity and Brand Personality: The Impact of Socially Desirable Responding. International Journal of Market Research 46 (2): 205-233. https://doi.org/10.1177/147078530404600201.

Holt, D., and D. Elliot. 1991. Methods of Weighting for Unit Non-Response. Journal of the Royal Statistical Society: Series D (The Statistician) 40 (3): 333-342. https://doi.org/10.2307/2348286.

Hornik, Kurt, Bettina Grün, and Michael Hahsler. 2005. Arules - A Computational Environment for Mining Association Rules and Frequent Item Sets. Journal of Statistical Software 14: 1-25.

Horovitz, J. 1979. Strategic Control: A New Task for Top Management. Long Range Planning 12 (3): 2-7. https://doi.org/10.1016/ S0024-6301(79)80001-1.

Hruschka, Harald. 2019. Comparing Unsupervised Probabilistic Machine Learning Methods for Market Basket Analysis. Review of Managerial Science, August 23. https://doi.org/10.1007/s11846-019-00349-0.

Kähkönen, Anni-Kaisa, and Katrina Lintukangas. 2018. Sustainable Supply Management Practices: Making a Difference in a Firm's Sustainability Performance. Supply Chain Management: An International Journal 23 (6): 518-530. https://doi.org/10.1108/SCM-01-2018-0036.

Kaplan, Robert, and David Norton. 1992. The Balanced Scorecard - Measures That Drive Performance. Harvard Business Review January-February: 71-79.

Keiningham, Timothy L., Bruce Cooil, Tor Wallin Andreassen, and Lerzan Aksoy. 2007. A Longitudinal Examination of Net Promoter and Firm Revenue Growth. Journal of Marketing 71 (3): 39-51. https://doi.org/10.1509/ jmkg.71.3.039. 
Keiningham, Timothy L., Lerzan Aksoy, Edward C. Malthouse, Bart Lariviere, and Alexander Buoye. 2014. The Cumulative Effect of Satisfaction with Discrete Transactions on Share of Wallet. Journal of Service Management 25 (3): 310-333. https://doi.org/10.1108/JOSM-08-2012-0163.

Kelleher, Bob. 2011. Engaged Employees Equals High-Performing Organizations (Achieving Successful Employee Engagement). Human Resource Management International Digest 19 (6). https://doi.org/10.1108/ hrmid.2011.04419faa.011.

Ketokivi, Mikko, and Saku Mantere. 2010. Two Strategies for Inductive Reasoning in Organizational Research. Academy of Management Review 35 (2): 315-333. https://doi.org/10.5465/amr.35.2.zok315.

Kihlstrom, John F., Eric Eich, Deborah Sandbrand, and Betsy A. Tobias. 1999. Emotion and Memory: Implications for Self-Report. In The Science of SelfReport, ed. Arthur Stone, Christine Bachrach, Jared Jobe, Howard Kurtzman, and Virginia Cain, 93-112. Psychology Press. https://doi.org/10.432 4/9781410601261-12.

Klaus, Philipp 'Phil', and Stan Maklan. 2013. Towards a Better Measure of Customer Experience. International Journal of Market Research 55 (2): 227-246. https://doi.org/10.2501/IJMR-2013-021.

Krosnick, Jon A. 1999. Survey Research. Annual Review of Psychology 50: 537-567.

Lumley, Thomas. 2011. Complex Surveys: A Guide to Analysis Using R. Hoboken: John Wiley \& Sons.

March, James G., and Robert I. Sutton. 1997. Crossroads - Organizational Performance as a Dependent Variable. Organization Science 8 (6): 698-706.

Marsh, Herbert W., and Lawrence A. Roche. 2000. Effects of Grading Leniency and Low Workload on Students' Evaluations of Teaching: Popular Myth, Bias, Validity, or Innocent Bystanders? Journal of Educational Psychology 92 (1): 202-228. https://doi.org/10.1037/0022-0663.92.1.202.

Martins, Luis L., and Ajit Kambil. 1999. Research Notes: Looking Back and Thinking Ahead: Effects of Prior Success on Managers' Interpretations of New Information Technologies. Academy of Management Journal 42 (6): 652-661. https://doi.org/10.5465/256986.

Mauboussin, Michael J. 2012. The True Measures of Success. Harvard Business Review, October 1. https://hbr.org/2012/10/the-true-measures-of-success

McDaniel, Carl, Jr., and Roger Gates. 2015. Marketing Research. Hoboken: John Wiley \& Sons.

Mintzberg, Henry. 1993. Structure in Fives: Designing Effective Organizations, Structure in Fives: Designing Effective Organizations. Englewood Cliffs: Prentice-Hall.

Neely, Andy, Chris Adams, and Mike Kennerley. 2002. The Performance Prism: The Scorecard for Measuring and Managing Business Success. London: Pearson Education. 
Palmatier, Robert W. 2008. Interfirm Relational Drivers of Customer Value. Journal of Marketing72 (4):76-89. https://doi.org/10.1509/jmkg.72.4.076.

PARP. 2011 . Raport o stanie sektora matych i'srednich przedsiębiorstw w Polsce. Ed. Anna Brussa and Anna Tarnawa. Warszawa: Polska Agencja Rozwoju Przedsiębiorczości.

Payne, Adrian, and Pennie Frow. 2017. Relationship Marketing: Looking Backwards towards the Future. Journal of Services Marketing 31 (1): 11-15. https://doi.org/10.1108/JSM-11-2016-0380.

Peppers, Don, and Martha Rogers. 2013. Extreme Trust: The New Competitive Advantage. Strategy and Leadership 41 (6): 31-34. https://doi.org/10.1108/ SL-07-2013-0054.

Pingitore, Gina, Neil A. Morgan, Lopo L. Rego, Adriana Gigliotti, and Jay Meyers. 2007. The Single-Question Trap. Marketing Research 19 (2): 9-13.

Pozza, Dalla Ilaria, Oliver Goetz, and Jean Michel Sahut. 2018. Implementation Effects in the Relationship Between CRM and Its Performance. Journal of Business Research 89: 391-403. https://doi.org/10.1016/j. jbusres.2018.02.004.

Reichheld, Frederick. 2003. The One Number You Need to Grow. Harvard Business Review, December: 1-11.

Reichheld, Frederick, and Rob Markey. 2011. The Ultimate Question 2.0: How Net Promoter Companies Thrive in a Customer. Boston: Harvard Business Publishing. https://books.google.pl/books?hl=pl\&lr=\&id=e8jhiYjQrU0C\&o $\mathrm{i}=$ fnd \&pg $=$ PR7 \& dq= reich held + markey \&ots $=\mathrm{CCl}$ eQacr8I\&sig $=\mathrm{iSgh}$ lWq6TPhrVgOpVEfeP3Hnzw\&redir_esc=y\#v=onepage \&q=reichheld $\% 20$ markey\&f=false.

Reimann, Martin, Oliver Schilke, and Jacquelyn S. Thomas. 2010. Customer Relationship Management and Firm Performance: The Mediating Role of Business Strategy. Journal of the Academy of Marketing Science 38 (3): 326-346. https://doi.org/10.1007/s11747-009-0164-y.

Reinartz, Werner, Manfred Krafft, and Wayne D. Hoyer. 2004. The Customer Relationship Management Process: Its Measurement and Impact on Performance. Journal of Marketing Research. https://doi.org/10.1509/ jmkr.41.3.293.35991.

Rong, Baiding, and Ian Wilkinson. 2011. What Do Managers' Survey Responses Mean and What Affects Them? The Case of Market Orientation and Firm Performance. https://doi.org/10.1016/j.ausmj.2011.04.001.

Rowley, Jenny. 2014. Designing and Using Research Questionnaires. Management Research Review 37 (3): 308-330. https://doi.org/10.1108/ MRR-02-2013-0027.

Samson, Alain. 2006. Understanding the Buzz That Matters: Negative Vs Positive Word of Mouth. International Journal of Market Research 48 (6): 647-657. https://doi.org/10.1177/147078530604800603. 
Sasser, W. Earl, Leonard A. Schlesinger, and James L. Heskett. 1997. Service Profit Chain. New York: Simon and Schuster.

Schertzer, Susan M.B., Clinton B. Schertzer, and F. Robert Dwyer. 2013. Value in Professional Service Relationships. Journal of Business \& Industrial Marketing 28 (8): 607-619.

Schmidt-Subramanian, Maxi, Harley Manning, Sam Karpinsky, and Shayna Neuburg. 2019. The Top 10 NPS Questions Answered What CX Professionals Should Know About Net Promoter Score. Forrester, November 7. https:// www.forrester.com/report/Executive+QA+Top+10+NPS+Questions+Answer ed+For+CX+Professionals/- /E-RES60925.

Schriesheim, Chester A. 1981. The Effect of Grouping or Randomizing Items on Leniency Response Bias. Educational and Psychological Measurement 41 (2): 401-411. https://doi.org/10.1177/001316448104100219.

Scott, W. Richard. 2002. Organizations: Rational, Natural, and Open Systems. 5th ed. Upper Saddle River: Prentice Hall.

Sharma, Aran, and Gopalkrishnan R. Iyer. 2007. Country Effects on CRM Success. Journal of Relationship Marketing 5 (4): 63-78. https://doi.org/10.1300/ J366v05n04_05.

Sharp, Byron. 2008. Net Promoter Score Fails the Test. Marketing Research 20 (4): 28-30.

Sheth, Jagdish N. 2017. Revitalizing Relationship Marketing. Journal of Services Marketing 31 (1): 6-10. https://doi.org/10.1108/JSM-11-2016-0397.

Shook, Christopher L., David J. Ketchen, G. Tomas M. Hult, and K. Michele Kacmar. 2004. An Assessment of the Use of Structural Equation Modeling in Strategic Management Research. Strategic Management Journal 25 (4): 397-404. https://doi.org/10.1002/smj.385.

Sterling, Theodore F. 2002. The Enron Scandal. New York: Nova Publishers. van de Mortel, Thea F. 2008. Faking It: Social Desirability Response Bias in SelfReport Research. The Australian Journal of Advanced Nursing 25 (4): 40.

Vij, Sandeep, and Harpreet Singh Bedi. 2016. Are Subjective Business Performance Measures Justified? International Journal of Productivity and Performance Management, June 13. https://doi.org/10.1108/IJPPM-12-2014-0196.

Whitlark, David B., and Gary K. Rhoads. 2011. Scoring Success. Marketing Research 23 (1): 8-13.

Zairi, Mohamed. 1994. Benchmarking: The Best Tool for Measuring Competitiveness. Benchmarking for Quality Management \& Technology l (1): 11-24. https://doi.org/10.1108/14635779410056859. 
Open Access This chapter is licensed under the terms of the Creative Commons Attribution 4.0 International License (http://creativecommons.org/licenses/ by $/ 4.0 /)$, which permits use, sharing, adaptation, distribution and reproduction in any medium or format, as long as you give appropriate credit to the original author(s) and the source, provide a link to the Creative Commons licence and indicate if changes were made.

The images or other third party material in this chapter are included in the chapter's Creative Commons licence, unless indicated otherwise in a credit line to the material. If material is not included in the chapter's Creative Commons licence and your intended use is not permitted by statutory regulation or exceeds the permitted use, you will need to obtain permission directly from the copyright holder. 